\section{Fertilizer Concentration and Moisture Tension Affect Growth and Foliar N, P, and K Contents of Two Woody Ornamentals}

\author{
Mary Ann Rose ${ }^{1}$, Mark Rose ${ }^{2}$, and Hao Wang ${ }^{3}$ \\ Department of Horticulture and Crop Science, The Ohio State University, \\ Columbus, OH 43210-1096
}

Additional index words. Acer $\times$ freemanii, Malus $\times$ zumi, water stress, irrigation, tensiometer, container ornamentals

\begin{abstract}
Crabapple [Malus $\times z u m i$ (Rehd.) 'Calocarpa'] and maple (Acer $\times$ freemanii E. Murray 'Jeffersred') trees were grown in containers from 22 June to 3 Oct. with three fertilizer concentrations $\left(50,100\right.$, and $\left.200 \mathrm{mg} \cdot \mathrm{L}^{-1} \mathrm{~N}\right)$ and two levels of moisture tension in the medium [low setpoint $($ moist $)=5 \mathrm{kPa}$ and high setpoint $($ dry $)=18 \mathrm{kPa}$ ]. Whole-plant growth was enhanced more by minimizing water stress than by increasing fertilizer concentration. Shoot length and whole-plant dry weight were greater $(>29 \%$ for crabapple and $>90 \%$ for maple) in low tension treatments (low water stress) but were unaffected by fertilizer concentration. Moisture tension also had a dominant effect on dry-weight allocation to leaves, stems, and roots. In contrast, foliar nutrient concentrations increased with fertilizer concentration but were affected to a lesser degree by moisture tension. Seasonal patterns in biomass allocation were little affected by treatments; the largest proportions of leaf and root biomass accumulated during summer and fall, respectively.
\end{abstract}

Water quality regulations and economics are pressuring container growers to use nutrients and water efficiently. Decreasing fertilizer runoff and water use without compromising plant quality are key challenges. Many studies have focused on the optimal fertilization rates required to produce the best plant with the least input (Bilderback, 1985; Jull et al., 1994; Stubbs et al., 1997) or on both timing and rate of fertilization (Maust and Williamson, 1994; Rose and White, 1994; Yeager, 1996). Another approach is to quantify the plant nutrient requirement by determining whole-plant recoveries (Rose et al., 1994; Struve, 1995).

With few exceptions, in most studies on nutritional requirements of container plants, water (and usually nutrients) has been applied on a poorly defined time-interval basis; water status of the plant or growing medium at the time of irrigation was not determined. The problem with this approach is that nutrient uptake is not a static response to nutrient availability; instead, it is a function of the plant's integrated response to its environment (Chapin, 1991). In agronomic crops, water stress at key growth stages limits crop response to applied nitrogen (Rhoads, 1984). Adequate water content in soils is required for

Received for publication 1 June 1998. Accepted for publication 17 Sept. 1998. Salaries and research support provided by state and federal funds appropriated to the Ohio Agricultural Research and Development Center, The Ohio State Univ. Manuscript no. 156-97. The cost of publishing this paper was defrayed in part by the payment of page charges. Under postal regulations, this paper therefore must be hereby marked advertisement solely to indicate this fact.

${ }^{1}$ Assistant Professor.

${ }^{2}$ Research Scientist.

${ }^{3}$ Research Technician. nutrient uptake. Low soil water potentials (high moisture tension) reduce nutrient movement to roots via diffusion or mass flow (Tisdale and Nelson, 1975).

Field-grown nursery stock generally responds more consistently to irrigation than to increasing $\mathrm{N}$ rate (Ponder et al., 1984; Wright and Hale, 1983). The primary objective of this experiment was to determine the relative effects of fertilizer rate and moisture availability on growth of container nursery plants, and to study biomass allocation in this context. Two woody perennials of importance to the landscape industry were chosen for this study.

\section{Materials and Methods}

Bare-root liners of crabapple $(120 \mathrm{~cm}$ height) and maple ( $45 \mathrm{~cm}$ height) were potted in 8.6- and 6.2-L plastic containers, respectively, using Metro Mix 510 growing medium (The Scotts Co., Marysville, Ohio). Trees were placed in an outdoor container yard in Columbus, Ohio, and were hand-watered for 6 weeks until roots were well established. Trees were blocked by stem diameters in a randomized complete-block design with four blocks. Treatments were applied between 22 June and 3 Oct., and consisted of factorial combinations of three fertilizer concentrations and two moisture tension levels. Fertilizer concentrations (FC) were 50, 100, and $200 \mathrm{mg} \cdot \mathrm{L}^{-1} \mathrm{~N}$ from soluble 24N-3.5P-13.3K fertilizer (Peters 24 8-16, The Scotts Co.). A system of Dosatron injectors (Dosatron International, Inc., Clearwater, Fla.), polyethylene tubing, and drip emitters $\left(4 \mathrm{~L} \cdot \mathrm{h}^{-1}\right)$ delivered fertilizer solutions to pots, which were covered to exclude rainfall.

Moisture tension (MT) levels consisted of two tensiometric setpoints: low tension (moist, higher irrigation frequency) $=5 \mathrm{kPa}$, and high tension (dry, lower irrigation frequency) $=18$ $\mathrm{kPa}$. Irrigation events were controlled by a Richdel 446 Controller (Hardie Irrigation, El Paso, Tex.) and mechanical switching tensiometers (model LTA; Irrometer Co., Riverside, Calif.). The controller queried tensiometers four times daily; irrigation occurred when setpoints were exceeded. Irrigation events never occurred more than three times per day. A single tensiometer was used to control each MT setpoint within each species. Each mechanical tensiometer was paired with an electronic recording tensiometer (Rose, 1994) that was placed in the same MT group, but not in the same pot. Data from recording tensiometers were collected via a real-time acquisition system (Rose, 1994). These data were closely inspected to ensure proper functioning of mechanical tensiometers and to determine irrigation frequency. Tensiometers were placed so that ceramic cups were $5 \mathrm{~cm}$ from the bottom of the pot, equidistant from the side of the pot and the stem axis.

Gravimetrically, the low-MT and highMT treatments represented $30 \%$ to $45 \%$ and $60 \%$ to $75 \%$ container capacity deficits, respectively. Crabapples received $\approx 1200 \mathrm{~mL}$ of fertilizer solution at each irrigation; maples received $800 \mathrm{~mL}$. These irrigation volumes represented $\approx 30 \%$ container capacity for the two container sizes. Thus, the goal of each irrigation was to restore container capacity in low, but not in high, MT treatments.

Three representative plants were harvested before treatments began to assess initial dryweight and nutrient status. One of two trees in each block $\times$ treatment $(n=4)$ combination was harvested on each of two harvest dates. One plant was destructively harvested 22 Aug. after terminal buds had set, and the other 10 Oct., just prior to leaf coloration. Leaf area was measured on the first date only (LI-3100 Area Meter; LI-COR, Lincoln, Nebr.). On both dates, shoot length, defined as the sum of all current-season shoot lengths, was measured, and leaves, stems, and roots were harvested for dry-weight and tissue N, P, K analysis (The Ohio State Univ. Research Extension Analytical Laboratory, Wooster). Plant N, P, and $\mathrm{K}$ contents were calculated by multiplying dry weights by nutrient concentrations. Leaf, stem, and root dry-weight gains for the summer (22 June-22 Aug.) and fall (22 Aug. -10 Oct.) growth periods were calculated by subtracting initial from final dry weights. Treatment effects were tested with separate analyses of variance for each species using PROC GLM, SAS statistical software (SAS Institute, Cary, N.C.). The regression of selected variables on total nitrogen applied also was performed using PROC GLM.

\section{Results and Discussion}

Plant growth. The statistical significance of treatments with respect to whole-plant growth measurements did not change between the two harvests, so data are presented from only the final harvest (Table 1). High MT significantly reduced whole-plant dry weight, 
shoot length, and leaf area in both species. Fertilizer concentration had no effect on dry weight or shoot length. Although there was a significant linear response of maple leaf area to FC, the relative effect of FC was much less than that of MT.

Previous studies of the relationship between FC and MT have been conducted primarily with greenhouse container crops. Lieth and Burger (1989) grew chrysanthemums [Dendranthema $\times$ grandiflora (Ramat.) Kitam.] at four levels of MT (1.5-15 kPA), using soluble fertilizer with each irrigation. They observed biomass reduction at the two highest levels of MT, but were unable to distinguish MT effects from nutritional effects on biomass because plants at high MT received lower total amounts of fertilizer. In the current experiment, the total amount of nutrients applied at equivalent $\mathrm{FCs}$ was $35 \%$ to $39 \%$ lower at high than at low MT (Table 1). Nonetheless, results suggested that whole-plant growth (dry weight, stem length) was not affected by FC or amounts of nutrients applied. Coefficients for the regression of dry weight and shoot length on total $\mathrm{N}$ applied were quite low (Table 2). Furthermore, the lowest levels of FC and MT supplied $62 \%$ less fertilizer than did the high FC/high-MT treatment, but dry weight of the crabapples was $30 \%$ greater with the former. In maple, the low FC/low-MT trees received $59 \%$ less fertilizer than the high FC/high-MT treatments, but dry weight was $120 \%$ greater. These results paralleled those of Shuch et al. (1995), who observed that moisture deficit had a much greater effect on biomass in poinsettias than did fertilizer concentration.

A gradient in water potential from high (in growing medium) to low (in atmosphere) is necessary for plants to absorb and transport water and minerals. A decrease in either major component of the water potential of the medium, osmotic or matric potential, can restrict water absorption (Marshall and Holmes, 1979). Other researchers (Dole et al., 1994; Shuch et al., 1995; Yelanich and Biernbaum, 1993, 1994) have found low or even negative correlations between plant growth and moderate rates of fertilization, and this may be related to fertilization effects on the water potential of the medium. Yelanich and Biernbaum (1990) observed no growth response in poinsettia to a 10 -fold increase in fertilizer concentration. However, when electrical conductivity (EC) in the medium exceeded 2 to $3 \mathrm{mS} \cdot \mathrm{cm}^{-1}$, fresh weight and bract area of poinsettias were reduced. Their data suggested that a decrease in the osmotic potential of the medium (higher EC) reduced growth and limited plant response to higher levels of nutrients. In the current experiment, the matric potential of the medium was manipulated by MT treatments and this had an overriding effect on growth relative to FC or total amounts of nutrients.

Foliar nutrient concentrations. Fertilizer concentration had linear and quadratic effects on foliar nutrient concentrations in both species (Table 1). Thus, while FC did not affect whole-plant dry weights, higher FC produced plants with higher nutrient concentrations (Table 1) and contents (data not shown). Ac-

Table 1. Effects of moisture tension level and fertilizer concentration on total quantity of N applied, growth, and foliar nutrient concentrations at final harvest (10 Oct.) for maple and crabapple (1996).

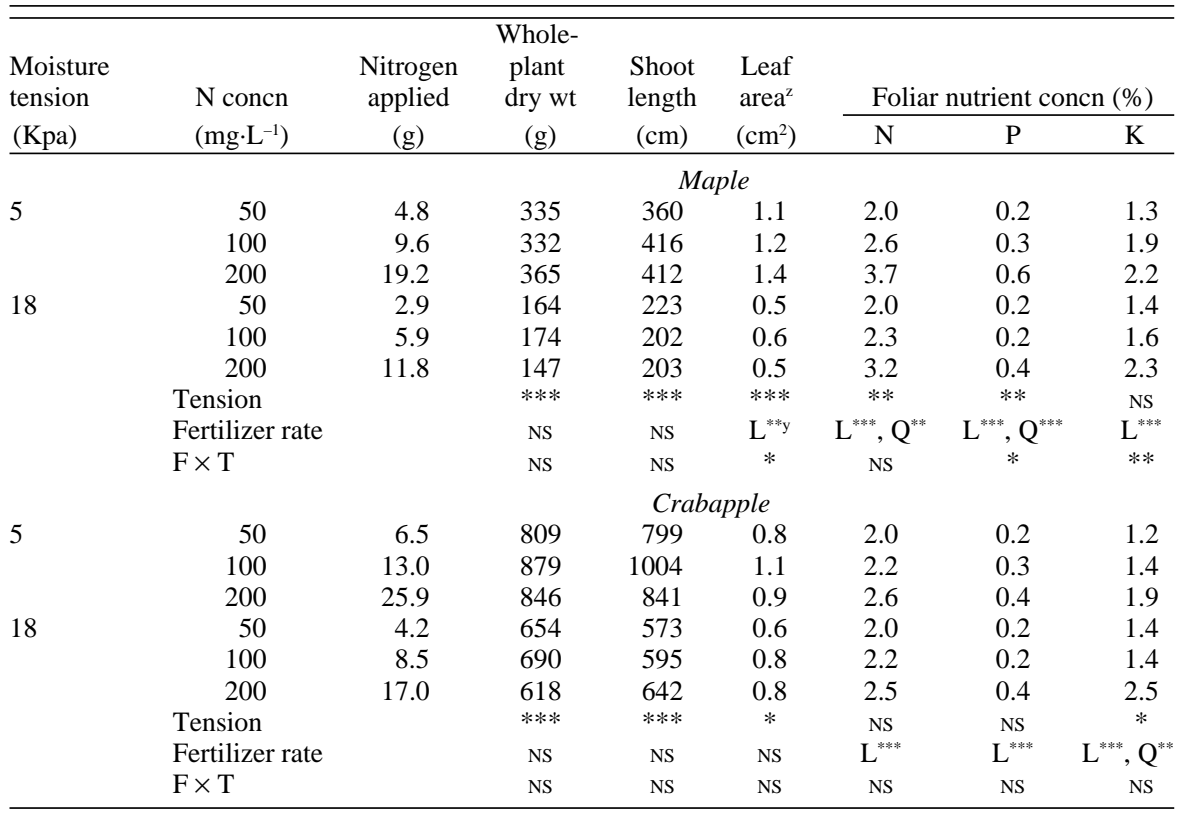

${ }^{\mathrm{z}}$ Leaf areas were measured on 22 Aug., not at final harvest.

${ }^{\mathrm{y}} \mathrm{L}=$ linear; $\mathrm{Q}=$ quadratic.

ss, ****,**** Nonsignificant or significant at $P \leq 0.05,0.01$, and 0.001 , respectively.

Table 2. Coefficient of determination $\left(R^{2}\right)$ for the linear regression of whole-plant dry weight, shoot length, and percentage of foliar N, P, and K on total N applied ${ }^{\mathrm{z}}$ to maple and crabapple, 1996.

\begin{tabular}{lccccr}
\hline Harvest date & $\begin{array}{c}\text { Dry } \\
\text { weight }\end{array}$ & $\begin{array}{c}\text { Shoot } \\
\text { length }\end{array}$ & $\mathrm{N}$ & $\mathrm{P}$ & $\mathrm{K}$ \\
\hline & & & Maple & \\
2 Aug. & 0.27 & 0.23 & 0.89 & 0.92 & 0.80 \\
10 Oct. & 0.22 & 0.23 & 0.90 & 0.88 & 0.72 \\
& & & Crabapple & \\
2 Aug. & 0.31 & 0.31 & 0.89 & 0.80 & 0.57 \\
10 Oct. & 0.10 & 0.19 & 0.76 & 0.66 & 0.40 \\
\hline
\end{tabular}

${ }^{\mathrm{z}}$ Total $\mathrm{N}$ applied is proportional to total $\mathrm{P}$ and $\mathrm{K}$ applied, so coefficients would be the same for regressions of these variables on total $\mathrm{P}$ and $\mathrm{K}$ applied.

cordingly, correlations between whole-plant dry weight and nutrient concentrations were very low (average for both species $R^{2}<0.12$ ).

High MT significantly reduced foliar N, P, and $\mathrm{K}$ concentrations of maple at one or more harvests (Table 1, only final harvest data shown). The $39 \%$ decrease in total fertilizer may have accounted for the small reduction in foliar nutrient concentrations in high- vs. lowMT treatments. Regression of foliar nutrient concentrations on $\mathrm{N}$ applied revealed a relatively strong association (Table 2).

Shuch et al. (1995) observed that moisture deficit did not affect foliar $\mathrm{N}$ concentrations. Results from the current experiment were similar in that MT had no effect, or a relatively small effect, on foliar nutrient concentrations, compared with FC. In crabapple, MT level did not affect foliar concentrations of $\mathrm{N}$ and $\mathrm{P}$ at either date (Table 1, only final harvest data shown). However, at final harvest, foliar $\mathrm{K}$ concentration was greater in high-MT trees despite the fact that these received lower total amounts of $\mathrm{K}$. The increase in foliar $\mathrm{K}$ concentration in crabapple at high tension invites speculation that this species is capable of osmotic adjustment to water deficit. Potassium salts of organic acids and sugars are the pri- mary osmotic components in non-halophytic higher plants (Hellebust, 1976).

Summer and fall biomass allocation patterns. Most of the leaf biomass accumulated during the summer growth period, except in crabapples receiving the lowest FC (Figs. 1 and 2). For those crabapples, summer and fall gains in leaf dry weight were nearly equal. Since terminal buds were observed in all plants by 22 Aug., leaf expansion or thickening accounted for any increase in leaf dry weight during the fall period.

With few exceptions, MT had a dominant effect on component biomass, particularly for maple (Table 3; Figs. 1 and 2). Nonetheless, FC had linear effects on some dry-weight components (Table 3). Leaf dry weight increased with FC in the summer (both species) whereas root dry weight decreased (crabapple). As a result, FC had an effect on shoot : root ratios in the summer (Table 4). Fall data suggest that the response of root dry weight to increasing FC may have been limited at high tension (Figs. 1 and 2). However, the FC $\times$ MT interaction was nonsignificant (Table 3 ).

Notable gains in root biomass (Figs. 1 and 2) and a corresponding decrease in shoot : root ratios (Table 4) were apparent in both species 

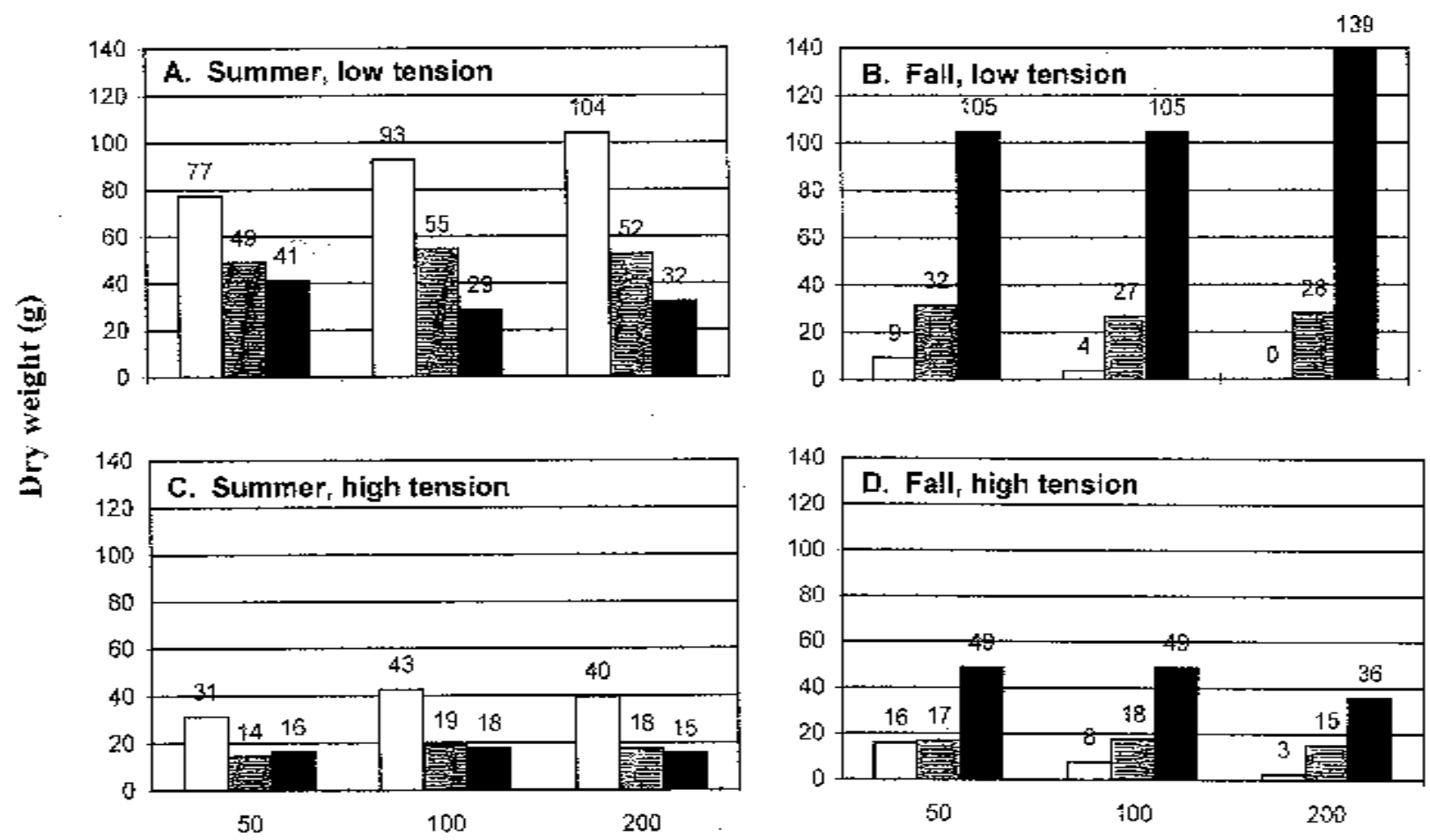

Nitrogen concentration in solution (mg $\mathbf{L}^{-1}$ )

Fig. 1. Effects of moisture tension and fertilizer concentration on summer and fall dry-weight gains in leaves, stems, and roots of maple. $\square=$ leaf dry weight, $\square=$ stem dry weight, $\mathbf{\square}=$ root dry weight.

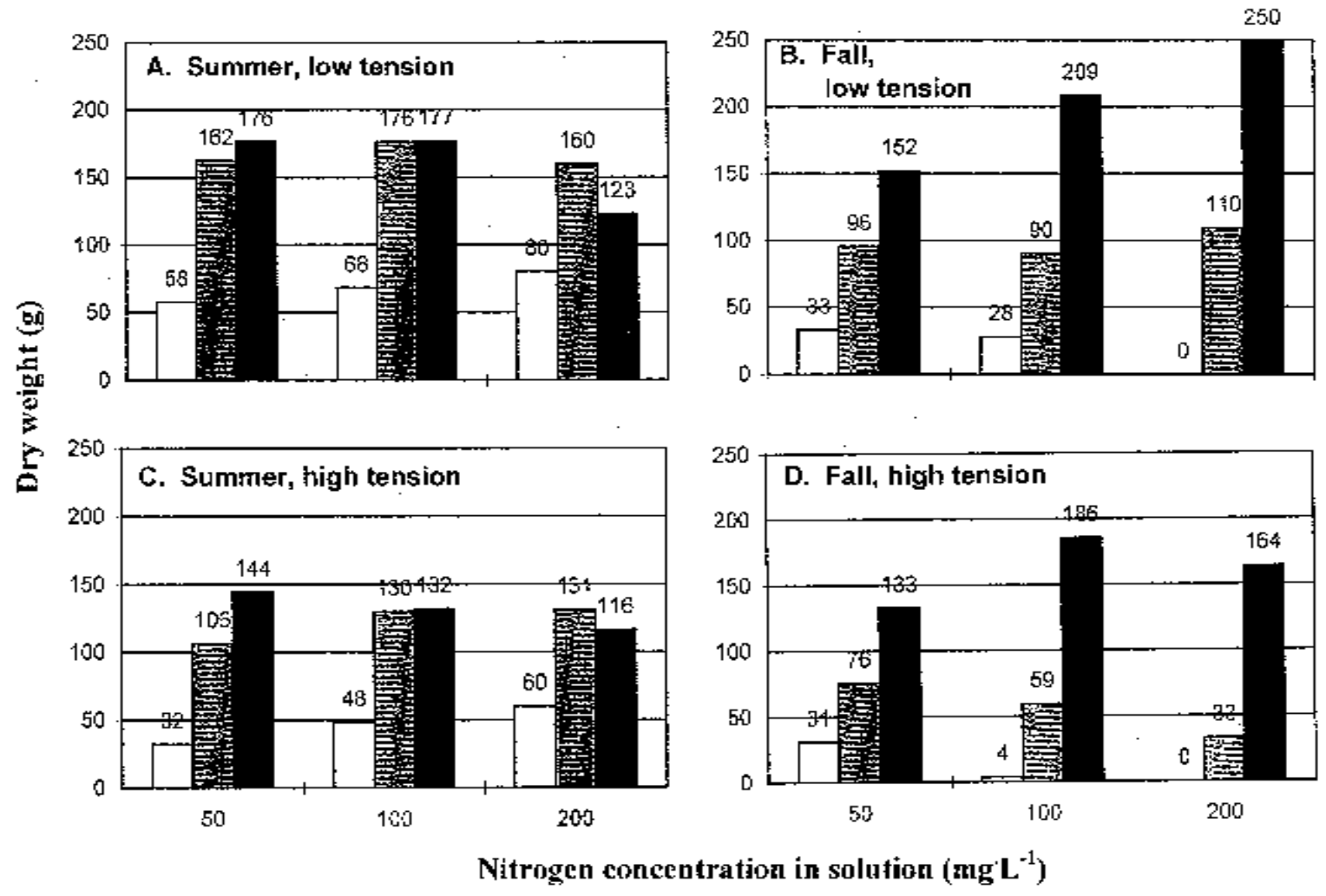

Fig. 2. Effects of moisture tension and fertilizer concentration on summer and fall dry-weight gains in leaves, stems, and roots of crabapple. $\square=$ leaf dry weight, $\square=$ stem dry weight, $\mathbf{\square}=$ root dry weight. 
Table 3. Summary of analysis of variance for leaf, stem, and root dry-weight (g) gains during summer and fall growth periods.

\begin{tabular}{|c|c|c|c|c|c|c|}
\hline & \multicolumn{2}{|c|}{ Leaves } & \multicolumn{2}{|c|}{ Stems } & \multicolumn{2}{|c|}{ Roots } \\
\hline & Summer & Fall & Summer & Fall & Summer & Fall \\
\hline & \multicolumn{6}{|c|}{ Maple } \\
\hline Tension (T) & $* * *$ & NS & $* * *$ & $* *$ & $* * *$ & $* * *$ \\
\hline Fertilizer $(\mathrm{F})$ rate & $\mathrm{L}^{* * * * \mathrm{z}}$ & NS & NS & NS & NS & NS \\
\hline \multirow[t]{2}{*}{$\mathrm{F} \times \mathrm{T}$} & NS & NS & NS & NS & NS & NS \\
\hline & \multicolumn{6}{|c|}{ Crabapple } \\
\hline Tension & $* * *$ & NS & $* * *$ & $* *$ & $* *$ & NS \\
\hline Fertilizer rate & $\mathrm{L}^{* *}$ & $\mathrm{~L}^{* *}$ & NS & NS & $\mathrm{L}^{* *}$ & NS \\
\hline $\mathrm{F} \times \mathrm{T}$ & NS & NS & NS & NS & NS & NS \\
\hline
\end{tabular}

${ }^{\mathrm{z}} \mathrm{L}=$ linear.

Ns, $* *, * * *$ Nonsignificant or significant at $P \leq 0.01$ or 0.001 , respectively.

Table 4. Effects of moisture tension and fertilizer concentration on shoot : root dry-weight ratios at two dates.

\begin{tabular}{|c|c|c|c|c|c|}
\hline \multirow{3}{*}{$\begin{array}{l}\text { Moisture } \\
\text { tension } \\
(\mathrm{Kpa})\end{array}$} & \multirow{3}{*}{$\begin{array}{l}\mathrm{N} \text { concn } \\
\left(\mathrm{mg} \cdot \mathrm{L}^{-1}\right)\end{array}$} & \multicolumn{4}{|c|}{ Shoot : root ratio } \\
\hline & & \multicolumn{2}{|c|}{ Maple } & \multicolumn{2}{|c|}{ Crabapple } \\
\hline & & 22 Aug. & 10 Oct. & 22 Aug. & 10 Oct. \\
\hline \multirow[t]{3}{*}{5} & 50 & 3.2 & 1.2 & 1.5 & 1.2 \\
\hline & 100 & 4.7 & 1.4 & 1.6 & 1.1 \\
\hline & 200 & 4.5 & 1.2 & 2.0 & 1.1 \\
\hline \multirow[t]{6}{*}{18} & 50 & 2.7 & 1.3 & 1.3 & 1.2 \\
\hline & 100 & 3.2 & 1.4 & 1.6 & 1.0 \\
\hline & 200 & 3.4 & 1.6 & 1.9 & 1.0 \\
\hline & Tension $(\mathrm{T})$ & *** & NS & NS & NS \\
\hline & Fertilizer $(F)$ rate & $\mathrm{L}^{* * * *}, \mathrm{Q}^{* \mathrm{z}}$ & NS & $\mathrm{L}^{* * * *}$ & NS \\
\hline & $\mathrm{F} \times \mathrm{T}$ & NS & NS & NS & NS \\
\hline
\end{tabular}

${ }^{\mathrm{Z}} \mathrm{L}=$ linear; $\mathrm{Q}=$ quadratic.

Ns, *, *** Nonsignificant or significant at $P \leq 0.05$ or 0.001 , respectively.

in the fall. During this period, whole-plant dry weight increased by an average of $67 \%$ (data not shown); root dry weight (Figs. 1 and 2 ) represented $73 \%$ and $66 \%$ of the dry-weight gains for maple and crabapple, respectively.

Species differences. Biomass production and shoot elongation were more sensitive to high MT in maple than in crabapple; dry weight and shoot length at high MT were reduced by $53 \%$ and $47 \%$, respectively, in maple, vs. $35 \%$ and $23 \%$ in crabapple (Table 1 ). The total volume of fertilizer solution was $35 \%$ (crabapple) and 39\% (maple) less at high MT; thus, dry-weight production per unit of water and nutrient in crabapple was the same at the two MTs. However, shoot elongation per unit of water and nutrient was more efficient at high MT in crabapple. Crabapples also were able to maintain equivalent $\mathrm{N}$ and $\mathrm{P}$ concentrations in foliage (Table 1) at the two levels of MT, whereas maples were not.

Shoot : root dry-weight ratios were the same (2.7) for both species at the beginning of the experiment. In the summer, crabapples allocated more dry weight to roots than to leaves; in maple the opposite was observed (Figs. 1 and 2). As a result, shoot : root ratios had increased in maple in most treatments by the first harvest (Table 4), while those in crabapple declined throughout the experiment. A lower shoot : root ratio in crabapple may explain why high MT had a less negative impact on biomass and shoot length in this species than in maple. Low shoot : root ratios have been linked to drought stress avoidance (Kummerow, 1980). A possible concern is that differences in pot size, rather than genetics, affected shoot : root ratios. Other research (Hanson et al., 1987; Menzel et al., 1994) indicates that increasing pot size increases shoot : root ratios, but crabapples in the larger pot size in our experiment had lower shoot : root ratios than did maples.

Both species had larger gains in root dry weight during the fall than during the summer (Figs. 1 and 2), although the difference was much greater in maple. Average gains in root dry weight were $26 \%$ greater in the fall for crabapple, and $220 \%$ greater for maple.

Conclusions. Nutrients are taken up by plants during periods of active root growth (Yeager et al., 1980). The substantial biomass accumulation in roots in all treatments between 22 Aug. and 10 Oct. suggested that early fall may be an important period for fertilization and irrigation. In many nurseries in the Midwest, growers restrict water and nutrients beginning in August and through early fall because of concern that irrigation and fertilization during this period will delay cold acclimation. An extensive review by Pellet and Carter (1981) suggests this precaution may be unnecessary. These authors and others (Bigras et al., 1996; DeHayes et al., 1989) have concluded that plants fertilized at levels promoting optimal growth are likely to acclimate as well as or better than low-fertility plants. Although contrary to current practice, results from our experiment suggest that the growth benefit from applying nutrients and water in early fall may be equal to fertilization during the rest of the growing season. Future research with additional species and different cultural practices is needed to determine the potential benefits.

Ornamental plants are graded and sold by size in the nursery industry; thus, there is an incentive to maximize growth. The substantial reduction in dry weight at high moisture tension suggests that timing irrigation to mini- mize moisture stress warrants as much attention as nutrition by nurserymen and researchers. Beeson (1995) grew three species of ornamentals at $20 \%, 40 \%, 60 \%$, and $80 \%$ container moisture deficits, and found that only the lowest moisture-deficit treatment produced acceptable size in all three species within the experiment's timeframe. Less frequent irrigation (higher deficit) did not detract from appearance, but reduced growth rate and increased the time required to reach marketable size. In the current experiment, plants grown under moisture stress (high MT) were similar in color and quality to low stress treatments at equivalent FC, but were more compact. In contrast, plants grown at different FCs and equivalent MT were distinguishable by intensity of leaf color, but not size. Plants grown at the lowest FC had lighter green foliage but were not chlorotic.

Results from this experiment suggest that growth may be more effectively maximized by reducing moisture stress than by increasing fertilizer concentration, at least in the range of fertilizer concentrations used in this study (50 to $200 \mathrm{mg} \cdot \mathrm{L}^{-1} \mathrm{~N}$ ). We do not refute Liebig's "Law of the Minimum," but rather suggest that water stress may limit growth more frequently than does limited nutrition under current container production practices. Furthermore, using lower concentrations of fertilizer (50 $\mathrm{mg} \cdot \mathrm{L}^{-1} \mathrm{~N}$ ) and maintaining low media moisture tensions may be an effective strategy to reduce nutrient runoff. Ensuring that plants do not wilt is not sufficient, since water stress may reduce yields or dry-weight accumulation without visible wilting (Rhoads, 1984). In this experiment, no wilting was observed in maple at high MT, and slight wilting of crabapple terminal growth was observed occasionally in August and September.

The mechanical switching tensiometer used in this experiment could be used by growers as an effective, low-cost tool for timing nursery irrigation to minimize water stress. The tensiometers required brief inspection and minor maintenance several times a week. Within a given block, the tensiometer should be placed in an indicator species that from experience requires most frequent irrigation. For use with container plants, the texture of the medium is an important consideration since these instruments do not function well in a coarse-textured medium. Also, optimal placement of the tensiometer in the container must be determined.

\section{Literature Cited}

Beeson, R.C. 1995. Managed allowed deficits in container moisture that produce commercially acceptable plants. Proc. Southern Nursery Assoc. Res. Conf. 40:364-367.

Bigras, F.J., A. Gonzales, A.L. D'Aoust, and C. Hebert. 1996. Frost hardiness, bud phenology and growth of containerized Picea mariana seedlings grown at three nitrogen levels and three temperature regimes. New Forests 12:243-259.

Bilderback, T.E. 1985. Growth response of Leyland cypress to media, $\mathrm{N}$ application and container size after 1 and 2 growing seasons. J. Environ. Hort. 3:132-135. 
Chapin, F.S. 1991. Effects of multiple environmental stresses on nutrient availability and use, $\mathrm{p}$. 67-88. In: H.A. Mooney, W.E. Winner, and E.J. Pell (eds.). Response of plants to multiple stresses. Academic, San Diego.

DeHayes, D.H., M.A. Ingle, and C.E. Waite. 1989. Nitrogen fertilization enhances cold tolerance of red spruce seedlings. Can. J. For. Res. 19:1037-1043.

Dole, J.M., J.C. Cole, and S.L. von Broembsen. 1994. Growth of poinsettias, nutrient leaching, and water-use efficiency respond to irrigation methods. HortScience 29:858-864.

Hanson, P.J., R.K. Dixon, and R.E. Dickson. 1987. Effect of container size and shape on the growth of northern red oak seedlings. HortScience 22:1293-1295.

Hellebust, J.A. 1976. Osmoregulation. Annu. Rev. Plant Physiol. 27:485-505.

Jull, L.G., S.L. Warren, and F.A. Blazick. 1994. Nitrogen nutrition of containerized Cryptomeriajaponica 'Elegans Aurea.' J. Environ. Hort. 12:212-215.

Kummerow, J. 1980. Adaptation of roots in waterstressed native vegetation, p. 57-73. In: N.C. Turner and P.J. Kramer (eds.). Adaptation of plants to water and high temperature stress. Wiley, New York.

Lieth, J.H. and D.W. Burger. 1989. Growth of chrysanthemum using an irrigation system controlled by soil moisture tension. J. Amer. Soc. Hort. Sci. 114:387-392.

Marshall, T.J. and J.W. Holmes. 1979. Soil physics. Cambridge Univ. Press, Cambridge, U.K.

Maust, B.E. and J.G. Williamson. 1994. Nitrogen nutrition of containerized citrus nursery plants. J. Amer. Soc. Hort. Sci. 119:195-201.

Menzel, C.M., D.W. Turner, V.J. Doogan, and D.R. Simpson. 1994. Root-shoot interactions in passionfruit (Passiflora sp.) under the influence of changing root volumes and soil temperatures. J. Hort. Sci. 69:553-564.

Pellet, H.M. and J.V. Carter. 1981. Effect of nutritional factors on cold hardiness of plants. Hort. Rev. 3:144-172.

Ponder, H.G., C.H. Gilliam, E. Wilkinson, J. Eason, and C.E. Evans. 1984. Influence of trickle irrigation and nitrogen rates to Acer rubrum. J. Environ. Hort. 2:40-43.

Rhoads, F.M. 1984. Nitrogen or water stress: Their interrelationships, p. 307-317. In: R.D. Hauck (ed.). Nitrogen in crop production. Amer. Soc. Agron., Madison, Wis.

Rose, Mark. 1994. Monitoring rose oscillatory transpiration by integrating a greenhouse climate control computer and physiological sensors. PhD Diss., Pennsylvania State Univ., University Park.

Rose, M.A. and J.W. White. 1994. Nitrogen rate and timing of nitrogen application in poinsettia $(E u-$ phorbia pulcherrima Willd. Ex Klotz.). HortScience 29:1309-1313.

Rose, M.A., J.W. White, and M.A. Rose. 1994. Maximizing nitrogen-use efficiency in relation to the growth and development of poinsettia. HortScience 29:272-276.

Shuch, U., R.A. Redak, and J. Bethke. 1995. Wholeplant response of six poinsettia cultivars to three fertilizer and two irrigation regimes. J. Amer. Soc. Hort. Sci. 121:69-76.
Struve, D.K. 1995. Nitrogen, phosphorus, and potassium recovery of container-grown red oak and blackgum seedlings under different fertilizer application methods. J. Environ. Hort. 13:169-175.

Stubbs, H.L., S.L. Warren, F.A. Blazich, and T.G. Ranney. 1997. Nitrogen nutrition of containerized Cupressus arizonica var. glabra 'Carolina Sapphire.' J. Environ. Hort. 15:80-83.

Tisdale, S.L. and W.L. Nelson. 1975. Soil fertility and fertilizers. 3rd ed. Macmillan, New York.

Wright, R.D. and E.B. Hale. 1983. Growth of three shade tree genera as influenced by irrigation and nitrogen rates. J. Environ. Hort. 1:5-6.

Yeager, T.H. 1996. Dwarf yaupon holly response to fertilizer application rate and frequency. HortTechnology 6:41-45.

Yeager, T.H., R.D. Wright, and M.M. Alley. 1980. Response of Ilex crenata Thunb. Cv. Helleri to timed fertilizer applications. J. Amer. Soc. Hort. Sci. 105:213-215.

Yelanich, M.V. and J.A. Biernbaum. 1990. Effect of fertilizer concentration and method of application on media nutrient content, nitrogen runoff, and growth of Euphorbia pulcherrima V-14 Glory. Acta Hort. 272:185-189.

Yelanich, M.V. and J.A. Biernbaum. 1993. Rootmedium nutrient concentration and growth of poinsettia at three fertilizer concentrations and four leaching fractions. J. Amer. Soc. Hort. Sci. 118:771-776.

Yelanich, M.V. and J.A. Biernbaum. 1994. Fertilizer concentration and leaching affect nitratenitrogen leaching from poinsettia. HortScience 29:874-875. 